\title{
O DISCURSO DO POEMA O RIO COMO EXPRESSÃO DO EU-LÍRICO NA POESIA DE JOÃO CABRAL
}

\section{THE SPEECH OF THE POEM THE RIVER AS AN EXPRESSION OF I- LYRICAL POETRY OF JOÃO CABRAL}

\author{
Maria de Fátima Gonçalves LIMA ${ }^{69}$
}

\begin{abstract}
RESUMO: $O$ rio, de João Cabral de Melo Neto, traduz a didática da poesia das águas, com sua construção, fluidez, prosopopeia e outras metáforas. A teoria literária desse discurso do poema exprime a imaginação formal e a imaginação material do momento que transpõe os labirínticos caminhos da passagem para o poético. Os resultados desta análise apontam para uma compreensão da sintaxe invisível das vozes líquidas das águas no instante em que lecionam poeticamente sua doutrina.
\end{abstract}

PALAVRAS-CHAVE: Poesia brasileira; Modernismo; João Cabral de Melo Neto; Discurso.

ABSTRACT: The River (O Rio), by João Cabral de Melo Neto, translates the didactics of the poetry of the waters, with its construction, fluidity, prosopopeia and other metaphors. The literary theory of the discourse of this poem expresses the formal and material imagination of the moment which raises the labyrinthine ways of the passage to the poetic level. The results of this analysis point towards an understanding of the invisible syntax of the liquid voices of the waters at the exact moment when they poetically teach their doctrine.

KEYWORDS: Brazilian poetry; Modernism; João Cabral de Melo Neto; Speech.

$O$ rio de João Cabral de Melo Neto exterioriza uma narrativa que traz a poética história do rio Capibaribe, o narrador-poeta-personagem dessa prosopopeia. Para seguir os elementos de análise desse discurso-rio, foram tomados por princípio os pressupostos da semântica gerativa de Greimas (1979) apresentados por José Luiz Fiorin (2000) no seu projeto teórico de análise do discurso. Adotando como modelo o percurso gerativo de sentido, a análise do poema será feita a partir das estruturas discursivas e sêmionarrativas nos seus componentes sintáticos e semânticos. Do primeiro, será feita uma

\footnotetext{
${ }^{69}$ Programa de Pós-Graduação em Letras. PUC-GO - Goiânia - GO - Brasil - fatimma@terra.com.br
} 
abordagem da sintaxe e da semântica discursivas, quanto à espacialização, tematização e procedimentos estilísticos; do segundo, o nível superficial será enfatizado a partir da semântica da narrativa até chegar ao nível profundo, que conduzirá à semântica fundamental e à essência do poema.

\section{O nível discursivo}

O poema narrativo $O$ rio tem as características do romance medieval. Esta espécie poemática ibérica, transmitida por via oral durante a Idade Média, normalmente era anônima e se caracterizava pela cursividade narrativa.

Ao narrar a própria história, o texto preserva os traços da tradição, uma vez que a voz poemática expõe suas impressões, lembranças, experiências e sentimentos. Existe um eu que narra poeticamente uma realidade vivida: "preferi essa estrada/ de muito dobrar,/ estrada bem segura/ que não tem errar/ pois é a que toda a gente/ costuma tomar/(na gente que regressa/ sente-se cheiro de mar)" (MELO NETO, 1994, p.120). Por outro lado, o eu poemático fala também das dores do mundo. Espécie de filósofo moderno, questiona a realidade sem medo de revelar o mundo do homem que conheceu. Para tanto, usa a geografia e a história da bacia do Capibaribe; utiliza a filosofia para refletir sobre aquela realidade e põe em prática a arte, quando poetiza aquele cenário e a própria experiência de vida. Deste conjunto, nasce um poema que narra a odisseia dos rios e dos homens, a caminho do mar. O rio, no papel de Odisseu, desnuda o universo das palavras, do homem e dos rios do sertão de Pernambuco.

Os versos do poema, ao descreverem as dores dos sertanejos, configuram um pessimismo que lembra o pensamento do autor de Dores do mundo e O mundo como vontade e representação, de Arthur Schopenhauer, quando este afirma: "O mundo é um inferno, e os homens dividem-se em almas atormentadas e em diabos atormentadores" (SCHOPENHAUER, s/d, p.33). A figura antropofágica dos usineiros faz da Usina símbolo do poder e destruição; os donos da terra comandam tudo e todos, numa ação contínua e desumana. Nesse movimento de poder e violência, os homens e a natureza são tragicamente consumidos: "Mas na Usina é que vi/ aquela boca maior/ que existe por detrás/ das bocas que ela plantou” (MELO NETO, 1994, p.131). 
A natureza do sertão está fadada à destruição e à morte. A inexorabilidade do destino vem demarcada por imagens que, de maneira progressiva, fazem-nos visualizar um espaço cada vez mais restrito e afastado, desde as matas à cova sepulcral:

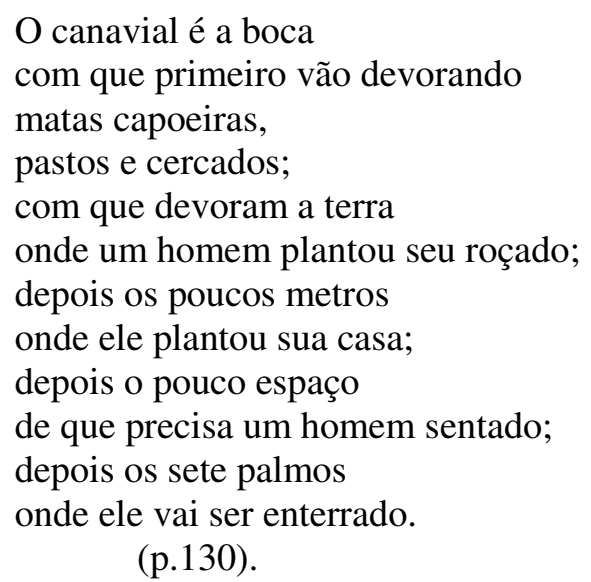

Esta estrofe é um exemplo do pessimismo no estilo shopenhaueriano que assinala em Dores do mundo (s/d, p.43) a seguinte concepção:

Assim como sob o ponto de vista físico o andar não é mais do que uma queda sempre evitada, da mesma maneira a vida do corpo é a morte sempre suspensa, uma morte adiada, e atividade do nosso espírito um tédio sempre combatido [...] É preciso enfim que a morte triunfe, pois lhe pertencemos pelo próprio fato do nosso nascimento e ela não faz senão brincar com a presa antes de a devorar.

Desta forma, o rio, poeta e filósofo, acorre para uma severa realidade, com nuances de negativismo, desesperança e, até mesmo, um certo nihilismo: "para a gente que desce/ é que nem sempre existe esse mar,/ pois eles não encontram/ na cidade que imaginavam mar/ senão outro deserto/ de pântano perto do mar" (MELO NETO, 1994, p.142). Nestes versos da penúltima estrofe, por exemplo, essa desesperança é bem marcada e a própria voz poemática tem a sensação de incapacidade - não sabe como ajudar essa gente: "É gente que assim me olha/ desde o sertão do Jacarará;/ gente que sempre me olha/ como se, de tanto me olhar,/ eu pudesse o milagre/ de num dia ainda por chegar,/ levar todos comigo,/ retirante para o mar" (p.142).

O discurso do rio interroga essa realidade e sua pergunta "(que lhe posso deixar,/ que conselho, que recado?)" (p.143) pode estar respondida na própria linguagem que, mesmo sem ter, necessariamente, o interesse e a eficácia do discurso comum, 
presentifica uma realidade por meio de metáforas, analogias e de uma retórica que transmite uma série de lógica e de significações, numa polissemia que pode ser compreendida por meio de leitura silenciosa, ou em alto e bom som, como aliás é a leitura ideal para o discurso desse rio. No final da última estrofe, apesar da gratuidade inerente ao texto artístico, a voz poemática põe em evidência que o seu discurso pode traduzir alguma relação metafórica entre os rios e essa gente: "somente a relação/ de nosso comum retirar;/ só esta relação/ tecida em grosso tear" (p.143). Esta conexão analógica é o ponto de partida para a presentificação do mundo real a ser revelado e, ao mesmo tempo, a materialização do texto artístico, num trabalho de pura metalinguagem. Esta dupla realização concebe a metáfora do mundo da arte.

$O$ rio, um poema narrativo com 60 estrofes de 16 linhas tem composição assimétrica, totalizando 960 versos. A extensão do poema, combinada com sua assimetria, metaforiza o mundo da bacia do Capibaribe que, realmente, nasce no município de Poção, limítrofe com o município de Jatuaúba, PE. A extensão desde a nascente até o Recife é de aproximadamente 220 a $240 \mathrm{~km}$. Estes números podem sugerir o sentido de que os 960 versos aludam a uma imagem quadrangular, por meio do número quatro, uma vez que 240 x $4=960$. O quadrado é, segundo Jean Chevalier e Alain Gheerbrant (1990, p.750), “o símbolo da terra por oposição ao céu, mas é também, num outro nível, o símbolo do universo criado, terra, céu, por oposição ao incriado; é antítese do transcendente”. Desta maneira, o quadrado é símbolo do terrestre, do sólido, do tangível e também da totalidade do criado e do revelado. Assim, o quatro é símbolo do mundo físico do sertão de Pernambuco, representa "as terras de sede [...] terra desertada/ vaziada, não vazia,/ mais que seca, calcinada./ De onde tudo fugia,/ onde só pedra é que ficava,/ pedra e poucos homens/ com raízes de pedra, ou de cabra" (p.120). Enfim, é um mundo dominado pela sede e pela dureza. Neste espaço, o Capibaribe nasce e caminha para o mar. Porém, logo aprende que é preciso lutar contra as intempéries do sólido, e que este comanda todo aquele espaço: seja através da imagem "do leito de areia/ com suas bocas multiplicadas" (p.119), ou nos dentes das usinas, ou na ferocidade da ambição do usineiro, ou na presença de qualquer natureza daquela paisagem - do mar de cana aos capinheiros. O quatro também significa a palavra em "situação dicionária" (p.351), parada, estagnada em si mesma. É a palavra 
no sentido denotativo, real, limitada de sentido, ainda no estado bruto, sem a fluidez da conotação.

Em contradição ao estado sólido do sertão e da posição estática da palavra em "situação de poço", está a polissemia e fluidez da linguagem poética e do rio Capibaribe com sua imensa bacia e dinamismo. Todos os rios caminham para o mar, todos representam o movimento para a transcendência, e também a marca do brando que consegue vencer o sólido: "numa usina se assiste/ à vitória de dor maior, do brando sobre o duro,/ do grão amassando a mó” (p.132). A água, símbolo e fonte da vida, metaforiza o renascer contínuo, da reiterada vitória da brandura do fluxo das águas sobre as pedras.

No plano da realidade, a oposição entre a água e a pedra transfigura a luta pela sobrevivência do homem sertanejo que batalha continuamente contra a seca, contra todos os vazios (a fome, a desumanidade), contra todas as negativas. Contraditoriamente, portanto, encontro da água com a pedra torna-se um momento produtivo, um instante menos perigoso do que o contato com o leito de areia. Não existe neste uma definição de direção, um caminho concreto, uma situação sólida contra a qual se possa lutar, caracterizando-se como negativa profunda, mortal e aporética. Existe só o vazio, o nada, o caos total do desconhecido. Na terra desértica não há perspectiva de luta, de direção, de caminho a seguir. A vida buscada no encontro com a solidez da pedra sertaneja, ainda que severina, franzina ou pétrea está condicionada a ter "raízes de pedra, ou de cabra" (p.120).

No sentido simbólico, a água exprime a transcendência e o espírito que marcam o signo da arte. Significa o Fiat, o ponto inicial do gênese, quando "o espírito de Deus pairava sobre as águas" (Bíblia Sagrada, s/d, p.550). Representa o movimento da ação que parte do princípio, antes do incriado. Parte do zero, com a sua forma de ovo cósmico, numa germinação, num início de acontecimento, na formação da fonte de uma unidade suprema e dinâmica: o rio da linguagem literária que sai do estado de poço e caminha para outras margens de significações. Neste instante de contemplação e mergulho no império silencioso das palavras e da realidade do Capibaribe, surge o canto desse discurso do rio da linguagem e o instante supremo da criação.

$\mathrm{Se}$, de fato, o rio se identifica com o princípio, pode, por analogia, representar-se pelo número um e este significa, antes de tudo, o ser humano, em especial o homem 
sertanejo, que é também o próprio verbo. "O um é símbolo do homem de pé: único ser que usufrui essa faculdade, a ponto de certos antropólogos fazerem da verticalidade um sinal distintivo do homem, ainda mais radical do que a razão" (CHEVALIER \& GHEERBRANT, 1990, p.918). Destarte, o numeral um representa o ser humano ativo, a palavra em ação, lutando contra uma dura realidade, mas com toda a sua força criativa. É deste ponto que emanam vida e arte, e a manifestação de ambas que "a ele que retorna, esgotada a sua existência efêmera: como o princípio ativo; o criador. $\mathrm{O}$ um representa o local simbólico do ser, fonte e fim de todas as coisas, centro cósmico e ontológico" (p. 918).

O rio pode representar o homem sertanejo e ao mesmo tempo sua arte, e, como tal, torna-se sujeito e número um, aquele ser que inicia a ação desse discurso e o conduz à totalidade. Ao simbolizar este numeral pode-se fazer uma analogia entre o simbolismo do homem e desse numeral. Sobre este último, Chevalier \& Gheerbrant (1990, p.919) expõem que o numero um tem a capacidade de assumir a posição de sujeito e de

toda a energia do símbolo unificador para realizar a si a harmonia do consciente e do inconsciente, o equilíbrio dinâmico dos contrários reconciliados, a coabitação do irracional com o racional, do intelecto com o imaginário, do real com o ideal, do concreto com o abstrato. A totalidade unifica-se na sua pessoa e a sua pessoa desenvolve-se na totalidade.

Este sujeito, rio ou homem ou palavra, simbolizável pelo número um está inserido dentro de uma realidade: o sertão ressequido, sólido - representado pelo quadrado. Portanto, o um não é a única representação desse espaço recriado. Existe um outro quatro vezes maior; um lugar pétreo, cabral: marcadamente sólido. Portanto, o número quatro pode ser assumido como a marca desse discurso, porque é a transfiguração física e metafísica do mundo do Capibaribe e da palavra poética.

Diante do exposto, $O$ rio tem o número quatro como múltiplo e é, nesta multiplicidade, que reside o significado dos 960 versos, das 60 estrofes, todas elas formadas por 16 versos e dos 28 quadros ou cenas compondo o seguinte desdobramento quaternário:

$960 \div 4=240 \div 4=60$

$60 \div 4=15$ 
$16 \div 4=4$

$28 \div 4=7$

A composição da estrofe por 16 versos tem um simbolismo significativo, uma vez que, sendo o quatro símbolo de solidez, materialização e metáfora da realidade do sertão nordestino, e posição estática da palavra em "situação de poço", o dezesseis (quatro x quatro) indica, sem dúvida, a realização da firmeza e da força material. Quatro ao quadrado representa a essência da força e solidificação do criado e revelado que não resulta de uma intenção humana. Esta força sólida e direcionada para um sentido, se opõe à polissemia e fluidez da linguagem literária e das águas deste rio da linguagem, que é um campo de ação, movimento e vontade humana. Tal intenção realiza uma obra literária composta por 60 estrofes de 16 versos e 28 cenas ou quadros.

Estas cenas ou quadros realizam a transfiguração da realidade do sertão de Pernambuco, na bacia do Capibaribe. Porém, este mundo real retratado nestes quadros não é uma simples cópia ou representação. É, na verdade, a criação de uma outra realidade: o discurso literário. E este, enquanto linguagem artística, pode repousar sobre uma realidade pré-existente, mas "admite-se, sem dúvida, que esta linguagem possa, de certa maneira refletir, na sua estrutura, os objetos, as idéias, as sensações que comunica, que ela possa, de algum modo, imitar o seu conteúdo" (LEFEBVE, 1980, p.18). Maurice-Jean Lefebve (p.21) expõe ainda que "a matéria da linguagem é, assim, convocada a pôr-se a si mesma em cena, o que leva muitas vezes a dizer que é a própria linguagem que fala".

A linguagem literária não se contenta em fotografar simplesmente uma realidade pré-existente; pelo contrário, o mundo real é um ponto de partida para a sua criação e para as interrogações que a arte se propõe, uma vez que de acordo com Lefebve (p.63), "a arte interroga o mundo sobre a sua realidade e a linguagem sobre a sua obsessão de uma adequação perfeita ao ser do mundo”. Roland Barthes (apud LEFEBVE, 1980, p.63) acrescenta que a linguagem literária é um "sistema semântico muito particular cujo fim é pôr "sentido" no mundo, mas não "um sentido". Daí resulta a tamanha força para fazer perguntas sem jamais lhes responder... e, por outro lado, que ela se ofereça a uma decifração Infinita”, na plurissignificação que reside no poético.

A imitação do mundo físico, dos acontecimentos ou mesmo a presença dos sentimentos individuais não é propriedade da arte poética. A poesia só pode ser 
descoberta na contemplação das palavras e estas têm o poder de atuar sobre o mundo, sobre as coisas, sobre os sentimentos individuais e deles extrair o artístico. Sem essa atuação das palavras, as coisas, as idéias não significam nada em termos literários. É necessário que o eventual assunto do poema (a dura realidade do sertão pernambucano, o curso do rio Capibaribe e a criação literária) encontre a forma de expressão linguística adequada. Mas, essa forma linguística não pode surgir por um trabalho apenas de inteligência: deve nascer espontaneamente da contemplação das palavras (aqui metaforizada pela concretude do sertão e pelo verbo criador). É neste contemplar que nasce o discurso do rio da linguagem artística que, quadro a quadro, cena por cena (28 vezes) nos 960 versos, vai revelando o poético, unindo forma e fundo, até a conclusão do curso do rio no mar de múltiplas ondas, margens e significações.

Neste final encontramos a marca da arte, o número 7, símbolo da perfeição e do mistério. Se dividirmos as 28 cenas por 4 (o número do sólido, da criação e revelação), chegaremos ao número 7, "símbolo universal de uma totalidade, mas de uma totalidade em movimento ou de um dinamismo total" (CHEVALIER \& GHEERBRANT, 1990, p.750), a tradução da arte e símbolo de toda a criação.

Esta totalidade do poema $O$ rio está expressa na reunião das 60 estrofes. Cada estrofe significa um conjunto de unidades ou versos do poema. Cada verso é uma imagem poética que, somada aos versos seguintes, ganha um reforço discursivo, sai do significado inicial e adquire novas significações e possibilidades de leitura. Esta polissemia provoca uma força no discurso poético análoga ao afluxo das águas excitadas pelo encontro com as pedras. Depois do choque entre o líquido e o sólido, o primeiro explode numa energia provocada pelo contato, causando "as vozes líquidas do poema" (p.55) com o seu barulho de acontecimento e ação. No texto poético, o mesmo procedimento pode ser observado em todas as estrofes e apresentado como um exemplo, no primeiro verso da $31^{\text {a }}$ estrofe do poema $O$ rio, denominada "Encontro com a Usina": "Mas na Usina é que vi” (p.131). Na leitura desta unidade, a imagem acústica da usina surge na memória do leitor, seguida do conceito (significado). Porém, a possível acepção da usina como um estabelecimento industrial, fábrica ou oficina, na significação denotativa, designativo do mundo real, ganha novos significados nas reiterações e associações concebidas nos versos seguintes: 


\begin{abstract}
aquela boca maior que existe por detrás

das bocas que ela plantou;

que come o canavial

que contra as terras soltou;

que come o canavial

e tudo o que ele devorou;

que come o canavial

e as casas que ele assaltou;

que come o canavial

e as caldeiras que sufocou.

Só na Usina é que vi

aquela boca maior

a boca que devora

boca que devorar mandou.
\end{abstract}

(p.131).

No segundo verso, o leitor se vê diante de novo significado da usina que, agora, não aparece com o conceito abstrato de indústria, mas com o de um de ser detentor de uma enorme boca devoradora, uma espécie de monstro, um símbolo do mal: "Aquela boca maior" (p.131) devora outra uma boca também muito perigosa: o canavial. Cada verso traz nova ideia do que poderia representar a usina, uma vez que aquele conceito denotativo agora é uma conotação, é uma metáfora, explicada em forma de informações, traduzindo o todo em partes, num processo metonímico: a usina é uma boca maior. Tal boca mastiga outra boca, que mastiga as terras, as casas, as caldeiras, tudo reiteradamente.

$\mathrm{O}$ ato de triturar com os dentes é representado por uma série de versos que ruminam repetidamente, como se estivesse mastigando o problema que está sendo explicado: "boca maior/ que existe(...) que come (...) que contra(...) que come(...) e tudo (...) que come (...) e tudo(...) que come (...)" (p.131). Toda a seção de versos é iniciada pela tradução de verbos que indicam certeza e pela adição de mais informações, para que o discurso, apesar de literário e, portanto, pouco transparente, seja comunicado.

A aludida reiteração de ideias e informações, além de produzir o espelho do ato de ruminar, repisar a imagem da violência e destruição provocada contra a vida daquela região, reflete também a própria imagem fluvial: o movimento ondulatório e sinuoso do fluxo das águas batendo nas pedras, expondo perturbações da massa fluida. Os versos são as linhas paralelas da corrente das águas formando curvas, tomando outras formas e rumos. 
Esta imagem fluvial percorre todo o poema $O$ rio, porém em algumas estrofes elas refletem as próprias ondas do mar, como pode ser observado na estrofe 32 :

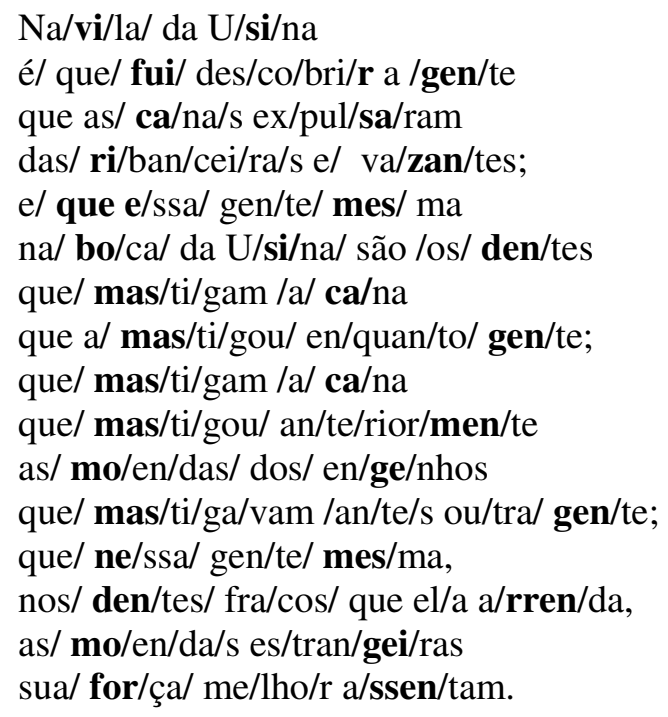
(p.131).

Os versos desta estrofe, assim como de todas que compõem o poema $O$ rio, possuem uma métrica irregular ou imperfeita, uma vez que existe uma pequena variação no número de sílabas poéticas de verso para verso. A métrica desse poema oscila entre, 5, 6, 7, 8, 9 e 10 sílabas. Esta aparente irregularidade significa a imagem das correntes do curso do rio, que na fluidez espalha fluxos variados, porém carregados de ritmo.

O ritmo determina essa fluviometria do poema. Quase todos os versos apresentam um ritmo que deixa evidente uma força sonora, no início e no final de cada verso. O mesmo processo acontece de forma cíclica em toda a estrofe: "que nessa gente mesma/ nos dente (...) arrenda/ as moendas estrangeira". Ao lado dessa acentuação no princípio e fim de cada verso existe um jogo entre os sons das vogais e consoantes, ora prevalecendo a aliteração, ora a assonância. Porém, mesmo quando o primeiro recurso está em evidência, os sons vocálicos chamam mais atenção. É o que pode ser chamado de vozes líquidas do poema, também já referidas nos versos de "O poema e a água" (p.55), numa alusão à capacidade de percepção de ideias e evocação que possuem os sons abertos. Tais sons podem ser considerados fluidos e detentores de uma grande capacidade comunicativa. Ao contrário dos sons consonantais, que exceto o (s) (com o seu poder de sugerir pluralidade), têm um poder de reter a mensagem. Numa analogia, podemos comparar as consoantes com as pedras: duras, sólidas, firmes, quase que 
intransponíveis. Por outro lado, as vogais têm a fluidez das águas: transparentes ou opacas, comunicativas, soltas, leves, transcendentais.

Na leitura em voz alta, o poema $O$ rio deixa os sons vocálicos fluírem como o barulho das águas batendo nas pedras: "Por esta grande usina/ olhando com cuidado vou, que esta foi a usina/ que toda esta Mata dominou. Numa usina se aprende/ como a carne mastiga o osso,/se aprende como mãos/ amassam a pedra, o caroço" (p.132). As águas quando encontram alguma dificuldade produzem um barulho de sonoridade aberta, semelhante aos sons vocálicos. Aqui também pode ser vista a metáfora da vitória do brando sobre o duro, aludida na imagem dos versos acima. Efetiva-se assim o resultado vitorioso do rio, sobre a dura realidade enquanto, história e o triunfo do poético sobre a dura realidade.

Em poesia, "o som", diz Pope, deve ser um eco do sentido (POPE apud LEFEBVE, 1980, p.69). Lefebve (p.69) acrescenta que "em verdade, o som deveria ser o próprio sentido. Mas somos forçados a contentarmo-nos com aproximações e com quase. A encarnação é ideal que só se aproxima na imitação ou na semelhança". Esta aludida encarnação realiza uma representação do espírito e esse momento provoca a ilusão de que os sons das vogais podem ser ouvidos por meio do barulho das águas. Este instante fica carregado de impressionismo e idealização, uma vez que "as vozes líquidas" (p.55) do poema são fluidas e cheias de opacidade. O som das vozes líquidas é quase virtual e mítico, imaterial e inexplicável. Existe apenas a sugestão ou imagem vocálica. Porém, no momento que a sugestão está sendo praticada, ou encarnada, acontece, segundo Lefebve (1980, p.69), “a tentativa de superar a contradição opacidade-transparência e de reaproximar a linguagem literária dessa linguagem adequada e original, essa linguagem em que o significante e o significado coincidem, essa linguagem dos deuses que é o mito da literatura".

Mas a arte aqui representada na canção fluvial não está apenas na sonoridade vocálica, ou fluida, comunicativa e branda. E, como já citamos anteriormente, a arte nasce justamente "onde a comunicação se quebra - ou, pelo menos, se altera -, como a faísca nasce de um curso-circuito" (p.36). O discurso do rio realiza um jogo entre o brando e o duro, entre o som vocálico e o consonantal, num processo alquímico que exprime uma realidade e traduz o mundo nas suas aparências e estrutura. Todo esse 
artifício criativo fica marcado pela abundância de significação inerente à inscrição artística.

Em quase todo o poema pode ser percebida ainda a imagem das águas em ação, quer seja em corredeira, como já sugerem estes primeiros versos: "Sempre pensara em ir / caminho do mar/ Para os bichos e rios/ nascer já é caminhar" (MELO NETO, 1994, p.119); ou ondas nas estrofes que apresentam o "Encontro com a Usina", "que mastigam a cana/ que mastigou enquanto gente;/ que mastigam a cana/ que mastigou anteriormente" (p.131). A ideia de uma situação - onda puxar outra, está reiterada nas estrofes 31 e 32, e em outras também, especialmente as que exprimem o mar de cana. Desta forma, a arte reflete o real na própria imagem discursiva.

Nesta ação imagética, muitas vezes aparece uma sintaxe invisível e calada, refletida no próprio silêncio do discurso. Este processo pode ser observado na $46^{\mathrm{a}}$ estrofe: "Um velho cais roído/ e uma fila de oitizeiros/ há na curva mais lenta/ do caminho pela Jaqueira,/ onde (não mais está)/ um menino bastante guenzo/ de tarde olhava o rio/ como se filme de cinema;/ viam-me, rio, passar/ com meu variado cortejo/ de coisas vivas, mortas,/coisas de lixo de despejo" (p.137). Na descrição da curva mais lenta, o discurso do rio é compassado e transmite uma imagem nostálgica e triste, sombreada pelos oitizeiros e pela aparência da ancianeidade e decrepitude do cais consumido pelo tempo.

Com uma nostalgia profunda, o rio contempla aquele espaço e vê, inserida na realidade severina, a figura franzina de um menino, também Severino. Este menino olha o rio e descobre, no curso das águas a caminho do mar, o próprio destino. Porém, o menino é uma palavra/pedra em situação dicionária, estava estagnado, parado, apenas Severino: não possuía a força daquele curso de água que ganhava novos sentidos em cada fluxo de ação. Ele, o menino, é um rio que não se fez, sem força suficiente para realizar seu sonho de buscar outras margens. Ele, o rio, olhava o menino e, também naquela figura humana e guenza, se reconhece: "Sempre pensara em ir / caminho do mar (...) Rio menino, eu temia/ aquela grande sede de palha/ grande sede sem fundo" (p.119). O rio olha o menino e, como num filme, vê passar a sua história de rio menino, num estado de poço ou numa pequena nascente na Serra do Jacarará. Como o menino, o rio também não tem consciência da sua situação dicionária, por isso afirmou "(não consigo me lembrar/ dessas primeiras léguas / de meu caminhar" (p.119). O menino 
exprime a transfiguração do rio da Serra do Jacarará e também símbolo dessa realidade severa. Por outro lado, o menino vê no rio a imagem do seu ideal refletida em forma de acontecimento, ação e construção de um mundo novo. Desta forma, a arte, ao contemplar a realidade, não fica encantada com a simples aparência da natureza, mas faz um mergulho na própria imagem e, através dela, descobre os traços de um possível real ofuscado pela visão da irrealidade da sua criação. A natureza por sua vez também busca na arte sempre o reflexo de si mesma numa posição narcisista. No entanto, neste reflexo fica evidenciada uma irrealidade, uma ilusão, um ideal distante de ser realizado.

Tal procedimento traduz a chamada "metáfora do abismo", que expressa uma espantosa e imensa diferença entre o menino e o rio, entre a realidade e a arte, entre o real e o imaginário, apesar das possíveis analogias. Neste momento, os dois param e fazem mútua contemplação: "um menino bastante guenzo/ de tarde olhava o rio/ como se filme de cinema" e, vice-versa, o rio olha o menino no processo denominado por Lefebve (1980, p.54) de "reflexo abissal: o mundo como espelho de si mesmo e a obra como espelho do mundo coincidem". Mas neste encontro narcíseo, cada um mergulha no próprio mundo: o menino, na sua realidade severa e estática; a arte, na sua irrealidade, fluidez e criação. Por este motivo, o discurso do rio nesta estrofe transmite uma sensação de estar parado ou de construir um abismo profundo de nostalgia, sentimento, lembranças num "variado cortejo/ de coisas vivas, mortas,/coisas de lixo de despejo" (p.137). Estamos diante do fascinante encontro entre a realidade pétrea e a fluidez da arte, num jogo antitético gerador de energia e força produtora do poético e, portanto, de imagens encantadoras que realizam a criação de um mundo de significações.

\section{Do nível narrativo ao fundamental}

De início, o caráter ficcional pode ser percebido uma vez que a voz anunciada pertence ao próprio rio Capibaribe, constituindo-se, portanto, numa prosopopeia. As situações vivenciadas pelo sujeito são as constatações experimentadas durante o percurso da sua nascente até o oceano, num jogo de ficção x realidade. Este dualismo traduz as duas faces da narrativa, uma vez que o rio expressa ficção e realidade ao mesmo tempo. 
A realidade pré-existente do rio Capibaribe está nas experiências do personagem ficcional. Desde a nascente do rio, todos os espaços são citados: a lagoa da Estaca, Apolinário, Alto Sertão, estrada da Ribeira, Poço Fundo, Couro d'Anta, estrada da Paraíba, riacho das Éguas, ribeiro do Mel, terras de Limoeiro, Ilhetas, Petribu, o canavial, os rios citados, o Tapacurá, as usinas e sua problemática, São Lourenço, Ponte de Prata, Caxangá, Apipucos, Madalena, primeiras ilhas, os cais de Santa Rita, as duas cidades descritas. Estas paisagens e questionamentos formam a verdadeira história do rio Capibaribe.

Por outro lado, os personagens dessa narrativa são rios e homens. Porém, estes últimos não têm voz, são narrados pelo rio Capibaribe que, por sua vez, insere uma ideologia de caráter revolucionário a caminho do mar e de outras margens de vida. Porém, no final os rios alcançam o ideal, chegam ao grande mar, mas os homens ficam estacionados no mar de lama. A voz narrativa, depois de contar sua odisseia, interroga sua participação e ideologia neste fim de história e segue seu inexorável caminho. Contudo, ao partir, narra a história dessa gente por meio da sua experiência poética e narrativa e, nesta realização, revela a condição humana.

Esta ação praticada pelo sujeito poético não possui, evidentemente, a eficácia e o interesse, nem a transparência do discurso quotidiano. "O discurso literário não se dirige, em geral, a nenhum interlocutor preciso: no limite, dir-se-ia que ele se fala sozinho. Trata-se, ainda, de um sinal de gratuidade" (LEFEBVE, 1980, p.36). Por outro lado, o rio exprime a difícil travessia do homem sertanejo e questões sociais e históricas de Pernambuco e utiliza o próprio discurso para falar sobre este mundo.

Desta forma, a narrativa do rio Capibaribe apresenta duas faces: Ficção - a prosopopeia x Realidade - o mundo real do rio Cabiparibe.

\section{Nível profundo}

O poema $O$ rio, do poeta pernambucano, não ficou detido numa simples representação do mundo exterior, numa espécie de cópia de um espaço históricogeográfico. O rio representa o Capibaribe, mas também conota uma visão de mundo sobre a concepção da própria criação literária. Destarte, ele transfigura um mundo real 
e, como tal, deixou de ser apenas natureza e foi personificado, ganhou voz e pensamento, para também ser traduzido numa intencionalidade literária.

Esta intenção literária produz duas consequências apresentadas por MauriceJean Lefebve em Estrutura do discurso da poesia e da narrativa (1980, p.39): “A primeira, é que esta linguagem se designa a si mesmo na sua materialidade e que a obra se anuncia (e se denuncia) como obra de arte: toda a linguagem literária é necessariamente figurada; ela é o indício da sua própria materialização." A esta realização metalinguística, este autor chamou também de conotação reflexiva, que consiste na "propriedade que advém ao discurso através da intenção literária, de se designar a si mesma enquanto discurso literário, enquanto literatura" (p.39).

A segunda consequência vai de par com esta materialização figurativa da linguagem. A obra chama para si novas significações, numa opacidade e pluralidade de interpretações. Esta polissemia abre possibilidade para uma plurissignifação, inclusive significar as coisas do mundo numa presença de um certo real que foi chamada de presentificação.

O poema narrativo do rio Capibaribe enuncia a denominada "conotação reflexiva", quer seja pela intencionalidade literária, ou em todo conjunto metafórico que compõe o espírito do texto artístico. O rio é, antes de tudo, literatura. Porém, ao refletirse, realiza a presentificação de um espaço geográfico e humano real. Presentifica, artisticamente, a história, a problemática econômica e social da bacia do rio Capibaribe. Nessa criação, existe um mecanismo denominado "realizante-irrealizante", defendido por Maurice-Jean Lefebve ao comentar a fascinante posição da "imagem mental que parece ganhar uma certa consistência e dá a impressão de estar prestes a 'realizar-se"” (p.12). E que, aplicado ao contexto do poema $O$ rio, esse jogo entre o real e o imaginário é expresso no discurso da voz que enuncia uma verdade presente na bacia do Capibaribe. Todas as paisagens e todos os problemas formam a mais pura realidade e vivência. É história, ciência, verdade. No entanto, este real torna-se irreal quando narrado por um sujeito que é, artisticamente, o próprio Capibaribe. Este personagem principal narra poeticamente a história de heróis, dos rios e dos homens, seus companheiros retirantes, aventureiros. O rio representa uma espécie de Ulisses, vive sua odisseia imaginária e ao mesmo tempo real, num jogo "realizante-irrealizante" construtor de efeitos fascinantes, só encontrados no mundo da arte. 
Tais efeitos são estabelecidos por níveis diversos e complexos mecanismos, o que provoca na obra literária um caráter de "duplo movimento: o primeiro, denominado centrífugo e pelo qual ela se abre ao mundo exterior e aos seus problemas e o segundo, centrípeto, tende, pelo contrário, fechar a obra sobre si mesma, a constituí-la como seu próprio fim e como seu próprio sentido" (p.14).

Na obra $O$ rio, a constituição desse duplo movimento pode ser comprovada. Quando o discurso literário levanta as questões sociais do Nordeste, especialmente os problemas sofridos pela população ribeirinha do Capibaribe e regiões vizinhas, a obra produz um movimento centrífugo, levando os problemas da realidade à tona, num retrato realista. Nesse momento, a voz poemática deixa de lado a questão essencial da literatura e faz um desvio, aparente, do centro da questão do artístico. Neste movimento, o rio expõe o questionamento sobre a realidade humana daquela região, faz uma denúncia das condições de vida miserável e da escravidão que apodrecem aqueles homens:

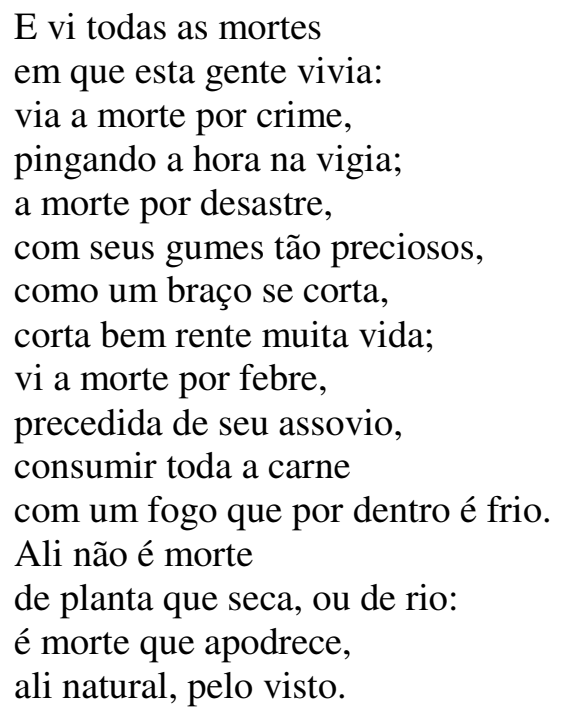

(MELO NETO, 1994, p.132/133).

Por outro lado, quando o discurso do rio usa o mundo real, apenas como um ponto de partida, para pensar na própria essência e no ser da arte, está diante do movimento centrípeto. Nesse momento, a arte é manifestada como o centro da existência do discurso do rio que dobra sobre si mesmo, em puro objeto de linguagem. É o instante denominado de materialização. 
O discurso do rio Capibaribe traduz toda uma dialética em torno da criação literária, uma vez que na semântica fundamental do seu discurso, partindo do mais concreto para o mais abstrato, foi constatado que existe um jogo dialético entre Rio Capibaribe x Rio poético, História x discurso, Real x imaginário, Ciência x arte, Linguagem eficaz ou interessada $x$ linguagem gratuita, Significado x Significante, Denotação $\mathrm{x}$ conotação, Transparência $\mathrm{x}$ opacidade, Movimento centrífugo $\mathrm{x}$ movimento centrípeto, Presentificação $\mathrm{x}$ materialização, Intencionalidade de comunicação (denúncia) x intencionalidade literária, Conteúdo x forma, Coletivo $\mathrm{x}$ individual. Sobre esse tema, Lefebve (1980, p.47) argumenta que

[...] a literatura é precisamente o campo dialético que se desdobra entre estes dois pólos, entendendo por dialética o fato de que nenhum destes pólos existe separadamente, que um é necessariamente a condição do outro, e que a materialização e a presentificação estão numa estreita relação de solidariedade: são elas que, no espaço assim aberto, constituem a imagem.

Nessas constatações sobre os elementos de análise do discurso, o rio produz um questionamento essencial, que está numa categoria ainda mais abstrata do que a dialética apresentada: o motivo que levou a voz poética a encarnar-se em rio. E esta causa realiza um prazer inerente à arte moderna, uma vez que, nessa prosopopeia, o prazer artístico triunfa sobre o humano, num processo denominado de "desumanização", em termos de Hugo Frierich em Estrutura da lírica moderna (1978, p.169):

Esta [a desumanização] se manifesta no abandono de estados sentimentais naturais, na inversão da ordem hierárquica, antes válida entre objeto e homem, deslocando agora o homem para o degrau mais baixo e na representação do homem partindo de um prisma que o fez parecer o menos possível com o homem.

Com fundamento nas observações do crítico, pode-se dizer que nesta obra de João Cabral de Melo Neto, O rio, está solidificada a simulação de uma renúncia ao humano.

Porém, a desumanização aqui presente constitui-se na renúncia do discurso humano, ou seja, àquela fala que constitui o instrumento da elite que se apossou das coisas e dos seres humanos para destruí-los em proveito próprio. Por esse motivo, a arte 
se consubstancia no rio Capibaribe, "o cão sem plumas", rio viajante, indigente, proletário, único ser capaz de ouvir o discurso dos outros rios, também operários, ouvir as dores daquele mundo de rios indigentes e homem desumanizados pela usura e pelo poder que a máquina afirma lhes proporcionar.

$O$ rio, com o seu silêncio e harmonia, passa a representar um sábio poeta que não pertence ao mundo dos homens e, por isso, está isento de responsabilidades e críticas da realidade. E, no posto de sua margem, isenção e arte, pode contemplar o mundo poética e filosoficamente. De sua contemplação nasceram os versos do seu discurso-rio, nos quais a voz poética exprime o desacerto do mundo por meio das marcas estilísticas de seus versos, que refletem sobre a própria construção literária.

O nível discursivo do trabalho artístico cabralino evidenciou a irregularidade métrica dos versos do poema. Tal irregularidade metaforiza toda a disjunção de um mundo caótico e desumano observado por esse rio-poeta-filósofo. Ora, como poderia esse poeta expressar, por meio de versos marcados pela regularidade, ações e realidades tão estranhas e inconcebíveis para os olhos humanos? Qual seria a melhor maneira para exprimir em versos a desumanidade do próprio homem? Com certeza, o nosso riopoeta-filósofo e, ao mesmo tempo, a própria arte em sua plena realização, transfigurou, com coerência, as imagens inusitadas que contemplou. Daí nasceu essa prosopopeia que, no seu estranhamento próprio da arte, presentifica uma realidade que poderia ser estranha se não fosse tão real. Tal concepção conduz ao célebre questionamento, a vida imita a arte, ou a arte imita a vida. Da primeira assertiva está patente um princípio certo e verdadeiro, a vida talvez seja muito mais estranha do que a arte. Por isso, as imagens aparentemente inusitadas do poema $O$ rio exprimem o estranhamento do ser da arte, que não se presta a uma simples imitação da realidade, tem sua autonomia e singularidade. Ela existe e basta. Cabe ao homem, que se diz humano, contemplá-la e, neste encontro, resgatar sua humanidade perdida no deserto de sua modernidade imaginada e cheia de poder e conquistas. Quem sabe nesse encontro, o homem perceba que a sua maior vitória está dentro do seu próprio rio existencial, e que este talvez seja também um Capibaribe a cantar versos irregulares de uma desumanidade perdida? Neste reflexo o homem pode ter salvação e nem tudo está disperso. 
Contudo, torna-se necessário esse mergulho no discurso-rio da linguagem para que se descubra o rio inexaurível do ser, sobre/para o qual Nietzsche (1950, p.608) escreve:

[...] ninguém pode construir em teu lugar as pontes que precisarás passar, para atravessar o rio da vida - ninguém, exceto tu, só tu. Existem, por certo, atalhos sem números, e pontes, e semideuses que se oferecerão para levar-te além do rio; mas isso te custaria a tua própria pessoa; tu te hipotecarias e te perderias. Existe no mundo um único caminho onde só tu podes passar. Onde levas? Não perguntes, segue-o.

Da mesma forma, $O$ rio de João Cabral de Melo Neto, nos 960 versos que o compõem, procede por meio de raciocínios imagéticos toda uma metáfora viva da existência do homem e da natureza em geral. Na fala proferida para o ser humano, o rio o conduz a uma reflexão sobre todas as coisas e, como um filósofo, mostra as verdades de forma abstrata e concreta. Cabe aos homens efetivar essa conscientização.

\section{REFERÊNCIAS}

BÍBLIA SAGRADA. Trad. Centro Bíblico de São Paulo. São Paulo: Ave Maria, 1981. CHEVALIER, J. \& GHEERBRANT, A. Dicionário de símbolos. Trad. Vera da Costa e Silva et al. Rio de Janeiro: José OLYMPIO, 1990.

FIORIN, J. L. Elementos de análise do discurso. São Paulo: Contexto, 2000.

FRIEDRICH, H. Estrutura da lírica moderna. Trad. Marise N. Curioni e Dora Ferreira da Silva. São Paulo: Duas Cidades, 1978.

LEFEBVE, M.-J. Estrutura do discurso da poesia e da narrativa. Trad. José Carlos Seabra Pereira. Coimbra: Almedina, 1980.

MELO NETO, J. C. Obra completa. Rio de Janeiro: Nova Aguilar, 1994.

NIETZSCHE, F. W. Obras completas. Buenos Aires: Aguilar, 1950.

SCHOPENHAUER, A. Dores do mundo. Trad. Assis Brasil. Rio de Janeiro: Ediouro, s/d.

O mundo como vontade e representação. Trad. Heraldo Barbury. Rio de Janeiro: Ediouro, s/d.

Artigo recebido em 07/09/2010 